Abstracta Iranica Abstracta Iranica

Revue bibliographique pour le domaine irano-aryen

Volume 34-35-36 | 2017

Comptes rendus des publications de 2011-2013

Charles-Henri de Fouchécour. Le sage et le prince en Iran médiéval. Morale et politique dans les textes littéraires persans, IX ${ }^{e}$-XIII ${ }^{e}$ siècles

Anna Livia Beelaert

(2) OpenEdition

Journals

Édition électronique

URL : http://journals.openedition.org/abstractairanica/41366

DOI : $10.4000 /$ abstractairanica.41366

ISSN : 1961-960X

Éditeur :

CNRS (UMR 7528 Mondes iraniens et indiens), Éditions de l'IFRI

Référence électronique

Anna Livia Beelaert, «Charles-Henri de Fouchécour. Le sage et le prince en Iran médiéval. Morale et politique dans les textes littéraires persans, IXe-XIIIe siècles », Abstracta Iranica [En ligne], Volume 34-35-36 | 2017, document 2, mis en ligne le 15 juillet 2016, consulté le 28 septembre 2020. URL : http://journals.openedition.org/abstractairanica/41366 ; DOI : https://doi.org/10.4000/ abstractairanica. 41366

Ce document a été généré automatiquement le 28 septembre 2020.

Tous droits réservés 


\title{
Charles-Henri de Fouchécour. Le sage et le prince en Iran médiéval. Morale et politique dans les textes littéraires persans, IX ${ }^{e}-X I I I^{e}$ siècles
}

\author{
Anna Livia Beelaert
}

\section{RÉFÉRENCE}

Charles-Henri de Fouchécour, Le sage et le prince en Iran médiéval. Morale et politique dans les textes littéraires persans, IX'e-XIII e siècles. Paris, L'Harmattan, 2009, ii + 511 + vi p.

1 Il s'agit ici d'une réimpression d'un livre magistral, paru en 1986 dans la bibliothèque iranienne à l'IFRI sous le titre Moralia, Les notions morales dans la littérature persane du $3^{\mathrm{e}} /$ $9^{e}$ au $7^{e} / 13^{e}$ siècle (voir Abs. Ir. 10, 1987, c.r. no 744) ; comme l'A. l'écrit à juste titre dans la courte préface qu'il a ajoutée, l'ouvrage était “depuis longtemps épuisé, n'a pas connu d'équivalent et reste une référence souvent citée" (p. i). Depuis ce quart de siècle déjà, l'importance de cette étude n'a été que confirmée et les chercheurs doivent être reconnaissants à L'Harmattan de rendre une étude si importante de nouveau disponible. Il est seulement à regretter que le site de cette maison d'édition ne précise pas qu'il s'agit d'une réimpression ; étant donné les différent titres et que l'A. est connu comme éminent spécialiste, il est vraisemblable que bien des bibliothèques qui ont déjà l'édition originale l'achèteront, même si de nos jours ils n'ont qu'un petit budget. Il est dommage aussi qu'il y a une coquille sur la couverture où on lit " $\mathrm{X}$ e siècle" au lieu de "IX". 


\section{AUTEURS}

ANNA LIVIA BEELAERT

Université libre de Bruxelles 